UDC 005. 336.2: 378.2 (510)

DOI https://doi.org/10.24919/2308-4863/45-2-24

Yanshi LIU,

orcid.org/0000-0002-6588-8325

PhD student

Kharkiv National University of Economics

(Kharkiv, Ukraine)

School of Foreign Languages, Sichuan University of Arts and Science (Sichuan,China)936533660@qq.com

\title{
THE APPROACHES TO IMPROVING THE CORE COMPETENCES OF BACHELOR-TRANSLATORS BASED ON THE SOCIAL DEMANDS
}

With the in-depth development of the market economy and the shift in the "language service" of translation, the social demands for the core competence of translators have become more and more specific, diverse and professional. Social recruitment units such as government departments, companies, and publishing houses put forward specific requirements for the core competence of bachelor-translators. This article is aimed to the research on the approaches to improving their core competence.

The concept of core competences has been analyzed on the basis of the literature in domestic and abroad researches. Compared with other similar concepts such as literacy and ability, the connotation of core competences covers the translator's quality, ability, consciousness, attitude, strategy and professionalism, which represents a set of knowledge, skills and attitudes.

These social needs from the relevant recruitment units are sorted out and analyzed, which have important practical values for the universities to improve the translation talent training model for educating more qualified and competent translators. Through material collections and analysis, the author has found that the social demands for translators are mainly concentrated in four aspects: translation competence, professional competence, cross-cultural communication competence, innovation competence and language service awareness.

By means of probes into announcements of recruitment from three types of organizations, on the basis of core competences' connotations, the findings are that Chinese universities in improving the bachelor-translators' competences should develop the professional standards of competence assessment based on their own advantages, explore localized talent training models, build data-based knowledge bases, create professional training platforms, promote the quality of talent training, and serve the needs of society and the country.

Finally, the author points out that Chinese universities should be timely, dynamic, and highly concerned about the society's demands for translators in different fields. The talent training objectives is more clarified in improving the cores competence of bachelor-translators, in the meantime, their market viability and adaptability will be enhanced.

Key words: translation talents, announcement of recruitment, social demands, core competence, "Teaching Guide for Undergraduate Translation Major".

Яньмі ЛЮ, orcid.org/0000-0002-6588-8325 аспірант,

Харківський національний економічний університет (Харків, Україна), Школа іноземних мов Університету мистецттв і наук у Сичуані (Сичуань, Kитай)936533660@qq.com

\section{ПІДХОДИ ДО ПІДВИЩЕННЯ БАЗОВИХ КОМПЕТЕНЦИЙ БАКАЛАВРІВ-ПЕРЕКЛАДАЧІВ НА ОСНОВІ СОЦІАЛЬНИХ ЗАПИТІВ}

Із поглибленим розвитком ринкової економіки та зміною «мовної служби» перекладу соиіальні вимоги до основної компетенції перекладачів стають усе більш конкретними, різноманітними та професійними. Соціальні підрозділи з набору персоналу, такі як державні відомства, компанії та видавництва, висувають конкретні вимоги до основної компетениії бакалаврів-перекладачів. Ця стаття спрямована на дослідження підходів до підвищення їхньої базової компетентності.

На основі вітчизняних та зарубіжних досліджень проаналізовано поняття ключових компетенцій. У порівнянні з іншими подібними поняттями, такими як грамотність $і$ здібності, конотація основних компетенцій охоплює якість, здібності, свідомість, ставлення, стратегію та професіоналізм перекладача, щчо представляє набір знань, навичок і ставлень. 
Liu Ya. The approaches to improving the core competences of bachelor-translators based on the social demands

Ці сочиіальні потреби від відповідних кадрових підрозділів відсортовані та проаналізовані, які мають важливе практичне значення для університетів у вдосконаленні моделі підготовки перекладачів для підготовки більш кваліфікованих і компетентних перекладачів. Зібравщи та аналізуючи матеріали, автор виявив, щзо соціальні запити до перекладачів переважно зосереджені в чотирьох аспектах: перекладацька компетентність, професійна компетентність, компетенція міжкультурного спілкування, інновачійна компетентність та обізнаність у мовних послугах.

Досліджуючи оголочення про прийом на роботу з трьох типів організацій, на основі конотацій основних компетенцій, ми з'ясували, щзо китайські університети для підвищення компетенції бакалаврів-перекладачів повинні розробляти професійні стандарти оцінки компетениії на основі власних переваг, досліджувати локалізовані моделі підготовки талантів, створювати бази знань на основі даних, створювати професійні навчальні платформи, просувати якість підготовки талантів та обслуговувати потреби суспільства та країни.

Нарешті, автор зазначає, щзо китайські університети мають бути своєчасні, динамічні та дуже стурбовані запитами суспільства на перекладачів у різних галузях. Завдання підготовки кадрів уточнюються у вдосконаленні базової компетенції бакалаврів-перекладачів, а тим часом їхня ринкова життєздатність та адаптивність буде підвищена.

Ключові слова: перекладацькі таланти, оголочення про прийом на роботу, соціальні запити, основна компетенція, «Навчальний посібник для студентів-перекладачів».

Introduction. With the development of market demand in the direction of diversification, refinement and specialization, as well as the shift of "language services" in translation, society has increasingly higher requirements for translators. As representatives of social demands, government departments, companies, publishing houses set definite requirements on the core competence of translators in their announcements of recruitment. An objective analysis of these demands will be helpful to grasp market development trends, provide a realistic basis for thinking about issues of talent preparation, timely and dynamically adjust professional training programs, explore localized training models, promote classroom teaching, optimize practical links, so that more proficient translators can be created with high translation competence and professional competence, strong cross-cultural communication and language service capabilities.

Analysis of recent research and publications. Since the 1980s, the topic of improving translator's literacy has been the focus of translation research and teaching. Compared with the broad concept of "translator", translation talents refer to those who have certain translation professional knowledge or skills, carry out creative translation activities and make contributions to the society. Translation professionals refer to bilingual talents in the field of translation and translation skills to help them achieve their successful communication. In the new era with IT, translators cover all kinds of talents who serve translation and operate translation industry. As language transfer is the core work in the language service industry, this paper will focus only on the professional bilingual personnel.

Core competences are related to quality and ability, which "represent a collection of knowledge, skills and attitudes. They are transferable and multifunctional. These competences are necessary for everyone to develop themselves, integrate into society and be competent for work" (Chu Hongqi,
2016). The academicians discussed core competences of translation talents from theoretical paradigms and disciplinary perspectives. Translation competence mainly refers to the strategies and skills adopted by the translator in solving the problem of bilingual transfer. Core competences are involved in the allround embodiment and display of the translator's quality, ability, consciousness, attitude, strategy and professionalism.

The success or failure of translation depends on the overall quality of translators. Eugene A. Nida pointed out that translators should have four basic qualities and abilities, namely bilingual ability, dual cultural cultivation, professional knowledge and expression ability (1993:134-137). With regard to personnel literacy, the Chinese translation academicians classify it into four modules: language skills, translation skills, knowledge accumulation and humanistic literacy, e, g. scholars such as (Song Wenling, 2015; Gu Feng, 2017; Zhang Shengxiang, 2017; Wang Hongyuan, 2018; Zhu Yifan, 2019) have made professional and multidirectional discussions on translation competence, language competence and professional competence, cross-cultural competence, psychological quality, information literacy, technical literacy.

The purpose - to attempt to find the improvement of bachelor-translator's core competence by means of the probes into announcements of recruitment from three types of organizations, so as to meet the demands of developing the language service industry, since the overall quality of translation talents in China is not very high in view of the current situation.

Main part. This study is based on four aspects in selecting main organizations: firstly, three types of units such as government departments, companies and publishing houses are selected, which cover the main recruitment units of translation talents, comprehensively reflect the overall needs of the society; secondly, the selected 60 samples are mainly in eastern China with the stronger demand 
for industrial talents, so as to ensure the universality of the regional distribution of the collected samples; thirdly, Chinese and foreign enterprises are considered in the selection of business companies, including both global language service providers and emerging network companies; finally, the announcements of recruitment within one year are screened to reflect the immediate talent demand.

- Data collection. With the advent of the financial media era, the release of recruitment announcements is not limited to the information platform. In addition, in some large websites such as Wechat public platform and official microblog, organizations also advertise information of recruitment for translators. In the process of collecting information, the timeliness, comprehensiveness and accuracy are ensured through multiple channels.

- Data processing. The recruitment information of various organizations is classified, focusing on retaining the job application; the common demands from the selected 60 samples are integrated, and the individual needs are separated; for the results of the data analysis, 10 authoritative units are selected from the three types to focus on the classification and analysis of their relevant data.

- Results and discussion. After classifying and counting the information of recruitment announcements from 60 organizations, the author found that their core demands for translation talents mainly focus on translation competence, professional competence, cross-cultural communication competence, innovation competence and service awareness (See Figure 1).

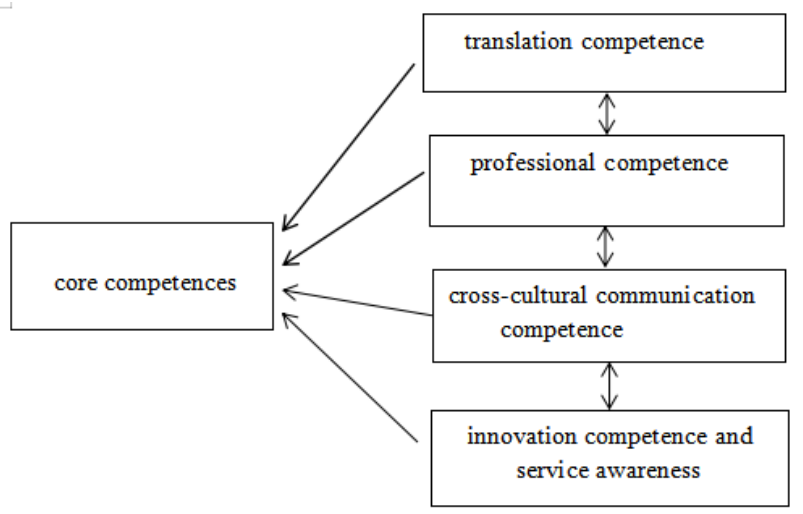

Fig. 1. The model for core competence of bachelor-translators

- Translation competence includes bilingual ability, translation ability, translation awareness, translation knowledge, etc. as language competence is the basis of translation. Government departments, companies and publishing houses all require specific needs for translators' professional competence, such as high bilingual understanding, writing and expression ability. Among the job recruitment from 60 samples, professional competence accounts for the largest proportion. In terms of qualification requirements, recruitment units are no longer limited to the professional certificates of language test. More recruitment units have clearly required candidates to pass the China accreditation test for translation and interpreting and obtain the certificate of Level 2 for the corresponding language.

- Professional competence mainly involves physical and mental quality, tool ability and working experience. All samples make clear provisions on the professional competence for recruitment. While completing the translation work with high quality, translators should have strong professional physical quality and skilled professional tool ability, and have an overall understanding of the translation project process or management.

- Cross-cultural communication competence includes communication skills and teamwork skills. The translator is required to maintain smooth communication with other translators, project managers, quality control personnel, customers, users, domain experts and other language service stakeholders in the project team, through exchange, sharing information and collaborative cooperation, so as to complete the translation work with quality and efficiency. Under the One Belt and One Road initiative, the transnational trade requires highly qualified and capable translation talents to provide high-quality language services for crosscultural business communication, and reduce the misunderstanding and conflict of trade culture caused by different cultures (Kravchenko G. Yu., Liu Yanshi, 2021). In this dimension, governments, business companies and publishing houses almost all require the translator's cooperation / coordination ability.

- Innovative competence refers to the abilities in innovative thinking and lifelong learning, which is the driving force for the sustainable development of the translator's career. Alibaba proposes that candidates should be open-minded, innovative, a thirst for knowledge. Huawei proposes that candidates should have strong learning ability. These announcements reflect the current social demand orientation for innovative and learning translation talents.

- Service awareness is one of the core competitiveness of employees in any industry and an embodiment of teamwork spirit. Bilingual transfer personnel not only serves the source language text and authors, but also considers the reading habits and acceptance methods of the target language 
audience, striving to achieve horizontal expectation in the two-way interaction, and provide all-round intellectual support for the cross-cultural exchange and transformation of text meaning.

Conclusions and suggestions. As the training bases for translation talents, universities should fully consider social demands when launching the bachelortranslators' training plan to improve professional level and maintain professional sustainable development. Since the undergraduate education is a key stage for translation talents, the National Standard for Teaching Quality of Foreign Language and Literature (2018) and the Undergraduate Teaching Guide for Translation Majors (2020) develop the professional standards for skill assessment and explore localized talent training modes. Only by building a data-based technical assessment platform and creating a professional practice platform can we educate professionals who serve the national strategy, regional development and social needs for the society.

- When strengthening practical teaching, we should develop a set of professional standards for the skills of translation talents, test the language skills and translation skills of students at different levels, conduct process evaluation, and track the quality of talent training in time. For example, in the training stage of undergraduate students majoring in translation, each training unit should consider (1) strengthening, testing, improving and correcting the language competence of students in the lower grades (Grades 1 and 2); (2) training the translation competence of senior students (Grade 3 and 4), and conducting synchronous tests; (3) cooperating with translation companies to receive training in professional translation skills and corresponding knowledge to improve students' professional competence.

- When formulating and revising the training plan, we should consider the market demand, social resources, regional location, professional teachers and other factors of the city, explore the professional path of specialization and localization. In particular, some universities can actively expand social resources, cooperate horizontally with enterprises and institutions, build translation platforms, introduce projects into the classroom and increase students' training opportunities according to the talent needs of social units. The mode of "taking social needs as the guide, taking professional standards as the criterion, relying on translation projects and focusing on practical training" (Zhang Shengxiang, 2017: 59) is commendable to prepare translation talents with strong knowledge, translation competence, learning ability, national emotion and wide international vision.

- Universities can build a data-based platform for translation learning knowledge, which can convert the generated quantifiable knowledge into intelligent knowledge, so as to guide students to learn translation. Teachers and researchers can also use it to carry out translation learning training and get feedback from translation teaching, or cognitive empirical research on the learning process through big data analysis.

- Universities also can create a professional practice platform. Translation projects are entered into the classroom while industry experts are invited into the university, which integrates the classroom content and social demands. Translation teachers train students to acquire the industry knowledge, technology, skills and literacy required by the language service market by inviting industry tutors into the classroom, project cooperation, field learning and simulation (Zhong Weihe, 2020: 82). Considering the practical features of translation major, we can execute the "double tutorial system" throughout the teaching process, so that students can have practical experience and cognition of the industry before professional learning, which greatly strengthens students' professional learning motivation and professional attitude.

Based on social needs, this paper has discussed how to train the qualified bachelor-translators. To conclude, Chinese universities should be timely, dynamic, and highly concerned about the society's demands for all kinds of translators, clarify the talent training objectives, improve the cores competence of bachelor-translators, enhance their market viability and adaptability. Through the investigation and analysis of recruitment announcements, four approaches are suggested to provide a reference for the application-oriented undergraduates. As an incubation base for translation talents, Chinese universities should maintain strategic concentration, strengthen researches on translation theory and practice, and build a translation talent training system with characteristics to make a positive contribution to the building of a global community of shared future as well as rapid economic development and industrial transformation and upgrading.

\section{BIBLIOGRAPHY}

1. Nida E. A. Language, Culture, and Translating. Shanghai: Shanghai Foreign Language Education Press, 1993.135 p.

2. Zhang Shengxiang. Analysis of social needs of translators' achievements and research of talent training models. Shanghai Journal of Translators. 2017. № 6. P. 53-62. 
3. Zhong Weihe. Research on the Development of the Translation Discipline and the Translation Profession in China (1949-2019). Journal of Chinese Translators. 2020. № 1. P. 79-86.

4. Chu Hunqi. Research and analysis of the demand for talent in the language and translation services industry - A case study of the 100 top language service providers (LSPs) in the world. Journal of East Translators. 2016. № 4. P. 1-6.

5. Кравченко Г. Ю., Лю Яньші. Сутність і структура міжкультурної компетентності майбутніх перекладачів. Імідж сучасного педагога : електронний науковий фаховий журнал. 2021. № 2(197). C. 42-47. URL: http://isp.poippo. pl.ua/article/view/227814 (дата звернення: 21.10. 2021).

\section{REFERENCES}

1. Nida E. A. Language, Culture, and Translating. Shanghai: Shanghai Foreign Language Education Press, 1993. 135 p.

2. Zhang Shengxiang. Analysis of social needs of translators' achievements and research of talent training models. Shanghai Journal of Translators. 2017. № 6. P. 53-62.

3. Zhong Weihe. Research on the Development of the Translation Discipline and the Translation Profession in China (1949-2019). Journal of Chinese Translators. 2020. № 1. P. 79-86.

4. Chu Hunqi. Research and analysis of the demand for talent in the language and translation services industry - A case study of the 100 top language service providers (LSPs) in the world. Journal of East Translators. 2016. № 4. P. 1-6.

5. Kravchenko H. Yu., Liu Yanshi. Sutnist i struktura mizhkulturnoi kompetentnosti maibutnikh perekladachiv [The essence and structure of intercultural competence of future translators]. The Image of Modern Teacher. 2021. № 2(197). C. 42-47. URL: http://isp.poippo.pl.ua/article/view/227814 (date of access: 21.10.2021) [in Ukrainian]. 